University of Nebraska - Lincoln

DigitalCommons@University of Nebraska - Lincoln

USDA National Wildlife Research Center - Staff Publications
U.S. Department of Agriculture: Animal and Plant Health Inspection Service

October 2007

\title{
Ecology and management of rodents in no-till agriculture in Washington, USA
}

\author{
Gary W. Witmer \\ USDA-APHIS-Wildlife Services, gary.w.witmer@usda.gov \\ Rodney Sayler \\ Washington State University, Pullman \\ David Huggins \\ Washington State University, Pullman \\ Jason Capelli \\ Washington State University, Pullman
}

Follow this and additional works at: https://digitalcommons.unl.edu/icwdm_usdanwrc

Part of the Environmental Sciences Commons

Witmer, Gary W.; Sayler, Rodney; Huggins, David; and Capelli, Jason, "Ecology and management of rodents in no-till agriculture in Washington, USA" (2007). USDA National Wildlife Research Center - Staff Publications. 732.

https://digitalcommons.unl.edu/icwdm_usdanwrc/732

This Article is brought to you for free and open access by the U.S. Department of Agriculture: Animal and Plant Health Inspection Service at DigitalCommons@University of Nebraska - Lincoln. It has been accepted for inclusion in USDA National Wildlife Research Center - Staff Publications by an authorized administrator of DigitalCommons@University of Nebraska - Lincoln. 


\title{
ORIGINAL ARTICLE
}

\section{Ecology and management of rodents in no-till agriculture in Washington, USA}

\author{
Gary WITMER, ${ }^{1}$ Rodney SAYLER, ${ }^{2}$ David HUGGINS ${ }^{2}$ and Jason CAPELLI ${ }^{2}$ \\ ${ }^{1}$ US Department of Agriculture/Animal and Plant Health Inspection Service/Wildlife Services, National Wildlife Research Center, \\ Fort Collins, Colorado, USA and ${ }^{2}$ Washington State University, Pullman, Washington, USA
}

\begin{abstract}
No-till farming is an important approach to sustainable agriculture because it can conserve soil and water resources. Unfortunately, rodent populations can thrive under no-till conditions because burrow systems are not disrupted by annual plowing and plant residues build-up on the surface, providing cover and insulation. This can result in substantial crop damage. We assessed rodent populations, habitat use, food habits, and crop damage in a no-till cropping system in Washington, USA. We also conducted preliminary trials of methods to reduce rodent populations and crop damage. In the fall, many more rodents were captured in fields with unharvested crops than in fields containing only plant stubble, suggesting that rodents leave fields after crop harvest, providing that suitable habitats are nearby, even when adequate cover is still available in harvested crop fields. By spring, the number of voles captured was much lower relative to fall. Despite this, capture rates were much higher in surrounding permanent grass areas than in crop (barley, wheat, pea) fields, suggesting that these grassy areas serve as refugia for rodents. Furthermore, the permanent grass cover type was the landscape variable most associated with rodent capture rates. In three winter pea fields, rodents removed $5-15 \%$ of the pea plants over winter. Examination of stomach contents revealed that voles mainly fed on grain plants in spring, but that their diet was more diversified in fall. Deer mice fed heavily on grain plants in both spring and fall, but also used insects as food. Metal barrier exclosures $(9 \mathrm{~m} \times 9$ $\mathrm{m})$, extending above and below ground, did not prevent access by rodents. Rodent populations in areas treated with zinc phosphide on grain were comparable to untreated areas 1 year after application of the rodenticide, perhaps because of immigration and recruitment, suggesting that baiting does not provide a long-term solution to rodent damage in no-till agricultural fields.
\end{abstract}

Key words: agriculture, damage, deer mouse, feeding ecology, Microtus, Peromyscus, rodent, vole.

\section{INTRODUCTION}

Crop fields provide habitat for a variety of wildlife species, which often results in crop damage (Wywia-

Correspondence: Gary Witmer, Supervisory Research Wildlife Biologist, USDA/APHIS/WS, National Wildlife Research Center, 4101 Laporte Avenue, Fort Collins, CO 80521-2154, USA. Email: gary.w.witmer@aphis.usda.gov lowski 1994; Conover 1998). Numerous species of birds and mammals contribute to crop losses. Worldwide concern, however, has focused on rodents, a large number of species of which cause substantial agricultural losses each year (Witmer et al. 1995). With the advent of effective herbicides and clean farming practices in North America, however, many rodent problems became less extensive (Hines \& Hygnstrom 2000). This is, in large part, because the fields were plowed each year, disrupting burrows and removing ground cover. The fields often lay 
bare for a large part of the year. The use of herbicides, plowing, and burning prevents fields from developing the vegetative cover that wildlife need for year-round food and shelter.

Recently, the use of conservation tillage or no-till agriculture has increased across much of North America, in part because these methods conserve soil and water resources (Phillips et al. 1980; Guy \& Cox 2002). Many pest problems can arise under no-till conditions, however, and an integrated pest management strategy is needed to deal with the weed, insect, and vertebrate pests that can proliferate and cause substantial damage in the no-till agriculture setting (Holtzer et al. 1996; Hammond \& Stinner 1999; Kogan \& Lattin 1999). When the ground is not plowed each year, intact burrow systems and crop residues are maintained, and surrounding areas provide suitable habitat for rodents, the potential exists for substantial increases in rodent populations, with subsequent crop damage (Johnson 1987; Bourne 1999). Research is needed to identify ways to reduce rodent damage in no-till agriculture (Johnson 1986): which species are involved, what are the patterns of habitat use, what are the seasonal changes in population dynamics, and what control or land-use measures could reduce damage?

The only tested and approved methods of reducing rodent populations and accompanying damage to crops are to: (i) manipulate (by burning, mowing, or herbicide spraying) the non-crop habitats (which may serve as rodent refugia) surrounding the crop fields; or (ii) apply rodenticides to the surrounding non-crop habitats or to apply (drill into soil along furrows) zinc phosphide pellets before or at the time of crop seed planting (Witmer \& VerCauteren 2001). Zinc phosphide on grain can effectively control rodent populations in areas of permanent grass cover (Witmer \& Fantinato 2003), but the agent is not registered for use on crop lands. Studies have suggested that some repellents and physical barriers may also reduce feeding, or access to food, by voles (Johnson et al. 1985; Merkens et al. 1991; Witmer et al. 2000), but no repellents are registered for use on field crops.

There are numerous species of microtines (subfamily Microtinae) throughout the Northern Hemisphere and at high population densities several become serious pests (Nowak 1991). In North America, many of the pest species belong to the genus Microtus, commonly called voles or meadow mice (Clark 1994; Edge et al. 1995). The main species in this area are montane voles (Microtus montanus), the major damage-causing rodents in the no-till setting of the present study, although other rodent species (deer mice, Peromyscus maniculatus, and west- ern harvest mice, Reithrodontomys megalotis) were present. The biology, ecology, characteristics, and distribution of voles, along with the types of damage caused, have been summarized by Pugh et al. (2003) and O'Brien (1994).

This study was conducted with the cooperation of Washington State University and the US Department of Agriculture's Agriculture Research Service, under the approved National Wildlife Research Center (NWRC) Project: Development and Evaluation of Rodent Damage Management Methods. This study was initiated because of an ongoing rodent damage situation occurring in experimental no-till agriculture plots in the area. In this study, we monitored rodent populations, distribution, habitat use, food habits, and crop damage. We also performed some preliminary trials of the effects of damage control methods on rodent populations.

\section{MATERIALS AND METHODS}

\section{Study area}

This study was conducted at the 96-ha Palouse Conservation Field Station (PCFS; N 46 $43^{\prime} 40^{\prime \prime}$ and W $\left.117^{\circ} 11^{\prime} 00^{\prime \prime}\right)$ in Whitman County, Washington. The area is characterized by the gentle rolling Palouse Hills with deep silt-loam soils, and would be covered with semi-arid steppe vegetation except for the intensive agriculture (wheat, barley, pea, and lentil production) practiced in the region. Higher elevation areas have conifer tree cover, but most areas not under cultivation have permanent grass cover (e.g. Festuca, Poa, Agropyron). The area is approximately $800 \mathrm{~m}$ above sea level, with approximately $50 \mathrm{~cm}$ of rainfall per year. Average temperatures range from $-2.2^{\circ} \mathrm{C}$ in January to $20^{\circ} \mathrm{C}$ in July. Long-term research studies of various aspects of no-till agriculture are conducted at the PCFS (e.g. on soil nutrients, water management, crop rotations, crop residue management, root diseases, and weed management). Permanent crop research plots at the PCFS vary in size and shape, which greatly influenced our rodent study plot locations and trap grid designs.

\section{Snap trapping for population data and food habits}

The study protocol (QA-918) was approved by the Institutional Animal Care and Use Committee of the USDA National Wildlife Research Center and by the Institutional Animal Care and Use Committee of Washington State University (Animal Subjects Protocol 3234). Data 
on rodent populations were obtained from animals collected in snap-trap grids generally operated for three consecutive nights. Collections were made in September 2001 (fall), April 2002 (spring), and September 2002. Each season, three snap-trap grids were placed in fields of each major crop (barley, wheat, pea) and in permanent grass cover areas surrounding the crop fields. All trap grids were at least $20 \mathrm{~m}$ from any other trap grid and from the edge of a crop of another type (with the exception of grassy strips as described below). Different areas were sampled each season so that previous trapping was less likely to influence the current and future trapping session. Snap traps were baited with peanut butter and rolled oats, set in the afternoon and checked early the next morning. A wire flag was placed near each trap and labeled with the trap's unique number. Generally, grids in crop fields contained 25 snap-traps in a $5 \times 5$ arrangement with $10 \mathrm{~m}$ spacing between traps. Trap grids were operated for three consecutive nights for 75 trap-nights per grid. However, the size and/or shape of some fields required an alternative grid design. For example, because the grassy area around the crop fields in most locations was rather narrow, two parallel rows of snap-traps, $5 \mathrm{~m}$ apart, were used with each pair of traps $10 \mathrm{~m}$ from the next pair along the lines with enough traps to allow 75 trap-nights over three consecutive nights. All trap data were converted to captures per 100 trap-nights to standardize this estimator of relative abundance. For each capture in each grid, date, location, crop or cover type, and species were recorded. The carcasses were placed in zip-lock bags, labeled and frozen for necropsy at a later date.

We used an ANOVA test to compare capture rates (number of captures per 100 trap-nights) in crops versus grass fields across seasons (fall 2001, spring 2002). We also compared the capture rates between cover types (unharvested crop versus stubble field; crop field versus grass field) within a season using $t$-tests. A $P$ value of $\leq 0.05$ was taken to indicate a significant difference between sample means.

At the time of necropsy, we recorded the species, weight, age class, sex, and reproductive status along with the date of capture, grid number, and crop or cover type. Stomachs were removed, placed in labeled bags, and frozen for later food habit analyses using micro-histological examination of plant fragments (Owsiak 1996). At least 10 randomly selected sub-samples of stomachs per crop per collection period were used. Carcasses were incinerated when no longer needed.

\section{Correlation of trap location with landscape variables}

Sherman live traps were used to capture rodents at 600 sites at the PCFS during spring, summer, fall, and winter in 2003-2004 (Capelli 2005). The traps were made of thin aluminum and were $24 \mathrm{~cm}$ long, $9 \mathrm{~cm}$ high, and 7.5 $\mathrm{cm}$ wide. Traps were baited with peanut butter mixed with oatmeal. Rodents were ear-tagged and released at the capture location to allow detection of recaptures. All 600 trap locations were sampled during fall 2003 for a single night, while 580-585 trap locations were sampled in each of the winter, spring, and summer 2004 seasons for three consecutive nights for a total of 5838 trap-nights.

We used eight environmental variables to explore potential relationships with seasonal rodent distribution patterns in the farm landscape, including cover type (grass, wheat, barley, pea, corn, and buckwheat/alfalfa), elevation (m), slope (\%), aspect (compass direction of slope), potential yearly soil radiation index (PYSR), soil moisture index (SMI), distance to field edge (m), and extent of field edges $(\mathrm{m})$ occurring within a $20-\mathrm{m}$ diameter of the trap location. A 2-m digital elevation model (DEM) of the PCFS was created in ArcGIS 8.3 (ESRI, Redlands, CA, USA), using the inverse distance-weighted method, from a series of 27000 geographic positioning system (GPS) locations and elevations accurate to $\pm 6 \mathrm{~cm}$. Elevation, slope, aspect, potential yearly soil radiation (PYSR), and soil moisture index (SMI) were the landscape variables calculated from the DEM for analysis. Slope and aspect were calculated from the DEM using the surface analysis tool in ArcGIS 8.3. Aspect was converted for improved interpretation using a TRASP transformation (Roberts \& Cooper 1989) calculated as: $1-\cos [(\pi / 180)($ aspect -30$)] / 2$. Soil moisture index was calculated from slope and specific catchment area as: soil moisture index $=\ln$ ([specific catchment area] $/ \tan [$ slope $]$ ). Specific catchment area is a catchment area draining across a unit width of contour (Wilson \& Gallant 2000) and is calculated from flow accumulation and flow direction. At each trap location, PYSR was also calculated using equations presented by Campbell and Norman (1998), modified to account for variations in slope and aspect. Distance-to-nearest-edge and meters of edge occurring within a 20 - $\mathrm{m}$ radius of the trap site ( $\mathrm{m}$ of edge) were calculated from the crop cover raster map using the plotted locations of field edges and trap locations. Stepwise logistical regression was used to model the landscape attributes that predicted rodent distribution patterns at the PCFS. 


\section{Crop damage estimation}

Crop damage in untreated (control) crop areas and in the treatment plots was assessed in April 2002 using 2-m transects placed along crop rows. Six or more transects were randomly placed in each field. A tape measure was stretched along each transect and the portion of the transect intersecting live plant cover was recorded (MuellerDombois \& Ellenberg 1974). The area damaged over winter by rodents was also assessed in three winter pea fields by mapping the damaged areas with a GPS unit. A geographic information system (GIS) software program was then used to calculate the area damaged relative to the entire field size.

We compared the percentage plant cover in damaged and undamaged areas of winter pea fields in spring using an ANOVA test.

\section{Test of barriers and rodenticides for reducing crop damage}

In an attempt to reduce crop damage by rodents, three treatments were put in place in November 2001, so that rodent populations and crop damage could be assessed in those areas the following spring and summer. All treatment areas were at least $20 \mathrm{~m}$ from any of the snap-trap grids (described above) used to obtain rodent population data. Treatment 1 , broadcast baiting with $2 \%$ zinc phosphide oat bait, was applied to four randomly selected $30 \mathrm{~m} \times 30 \mathrm{~m}$ plots, two in winter pea fields and two in permanent grass fields. Bait was applied with a fertilizer spreader at the label application rate of $33 \mathrm{~kg} \mathrm{ha}^{-1}$. Treatment 2 consisted of the placement of metal barriers to prevent rodent access to crops. Each barrier was approximately $9 \mathrm{~m} \times 9 \mathrm{~m}$ on a side and made of aluminum flashing with approximately $25 \mathrm{~cm}$ projecting above ground and $25 \mathrm{~cm}$ extending below ground. Nine barriers were constructed with three each placed randomly in winter pea, winter barley, and winter wheat fields. Once constructed, rodents within the barriers were removed using snap traps and application of $2 \%$ zinc phosphide bait. Treatment 3 consisted of metal barrier walls placed between permanent grass fields and winter pea fields in an effort to prevent rodent access to the crop field. Three barrier walls, each approximately $47 \mathrm{~m}$ long were constructed as described in Treatment 2 except that the barrier walls were linear, not square. Hence, these field edge barriers did not encompass the entire crop field, but only a portion of the perimeter. Rodents were removed from the crop side of the barrier walls as described for treatment 2. Capture rates behind barrier walls were com- pared with capture rates in areas without barrier walls. The effectiveness of each treatment was assessed using $t$-tests.

\section{RESULTS AND DISCUSSION}

\section{Rodent use of crop fields and grassy areas}

There were significant differences in capture rates between seasons and between crop fields and grass fields $(F=24.7$, d.f. $=3, P<0.0001$; Table 1). Significantly higher capture rates occurred in both crop fields (45.6 per 100 trap-nights; henceforth $=\mathrm{t}-\mathrm{n})$ and grass fields $(27.0$ per $100 \mathrm{t}-\mathrm{n}$ ) in the fall than in the spring (crop fields, 5.03 per $100 \mathrm{t}$-n; grass fields, 10.2 per $100 \mathrm{t}-\mathrm{n}$ ). Hence, unharvested crops and grass fields provide better habitat than fields in which the crops have been harvested and only plant residues remain or grass fields that are not actively growing in early spring. Additionally, the capture rates were significantly higher in fall crop fields than in the fall grass fields. This trend reversed in the spring whereby capture rates were higher in grass fields than in crop fields, although the difference was not significant. Hence, it appears that the grass fields provide better habitat for rodents through the winter and into early spring before crop fields have begun substantial growth to provide food and cover. Once the crops are harvested in the fall, the ability of those fields to support rodents drops quickly: unharvested crop fields had significantly higher capture rates (15.2 per $100 \mathrm{t}-\mathrm{n})$ than harvested crop fields $(6.7$ per $100 \mathrm{t}-\mathrm{n})$ that had only some stubble $(t$ $=6.3$, d.f. $=6, P<0.0006$; Table 1$)$. The height of standing plant residues in the harvested fields varied by crop type: $7.5-12.5 \mathrm{~cm}$ in pea fields, $17.5-20 \mathrm{~cm}$ in barley fields, and $40 \mathrm{~cm}$ in wheat fields. It appears, however, that the food and cover resources in the harvested fields were not very supportive of rodents despite the dry plant residues that remained.

Johnson (1987) noted capture rates of 1-34 deer mice per 100 trap-nights in both conventional tillage and no-till fields in Idaho and Washington. Our capture rates were often much higher in some fields: a Canadian corn field ( 80 per $100 \mathrm{t}-\mathrm{n})$, a winter wheat field (61.3 per 100 $\mathrm{t}-\mathrm{n})$, a regular corn field (55.2 per $100 \mathrm{t}-\mathrm{n}$ ), and a spring barley field (50.0 per $100 \mathrm{t}-\mathrm{n})$. The corn fields tended to have a greater occurrence of other plant species amongst the rows of corn, which may provide more food and cover for rodents. The Canadian corn was a short $(35 \mathrm{~cm})$ variety, whereas the regular corn field had a plant height of about $150 \mathrm{~cm}$.

At the time of the fall 2001 trapping session, it ap 
G. Witmer et al.

Table 1 Rodent captures per 100 trap-nights for various crop fields, stubble fields, and grass fields at the Palouse Conservation Field Station, Pullman, Washington, 2001-2002

\begin{tabular}{|c|c|c|c|}
\hline Crop/field & Captures per 100 trap nights & Crop/field & Captures per 100 trap nights \\
\hline September 2001 & & April 2002 & \\
\hline Growing crop & & Growing crop & \\
\hline Canadian corn & 80.0 & Winter wheat & 6.7 \\
\hline Winter wheat & 61.3 & Winter wheat & 0.0 \\
\hline Regular corn & 55.2 & Winter wheat & 9.3 \\
\hline Spring barley & 50.0 & Winter barley & 2.7 \\
\hline Spring pea & 42.5 & Winter barley & 8.0 \\
\hline Perm. grass & 36.0 & Winter barley & 5.3 \\
\hline Perm. grass & 33.8 & Winter pea & 6.7 \\
\hline Safflower & 31.3 & Winter pea & 1.3 \\
\hline Winter wheat & 28.8 & Winter pea & 5.3 \\
\hline Perm. grass & 11.3 & Overall mean & $5.0(3.1)$ \\
\hline Overall mean & $43.0(19.4)$ & Perm. grass & \\
\hline Stubble field & & Grass field & 9.3 \\
\hline Spring wheat & 12.0 & Grass field & 10.7 \\
\hline Winter pea & 9.0 & Grass field & 10.7 \\
\hline Winter pea & 6.0 & Overall mean & $10.2(0.8)$ \\
\hline Spring barley & 5.0 & & \\
\hline Winter barley & 5.0 & September 2002 & \\
\hline Winter wheat & 3.0 & Stubble field & \\
\hline \multirow[t]{13}{*}{ Overall mean } & $6.7(3.3)$ & Winter wheat & 2.0 \\
\hline & & Winter wheat & 4.2 \\
\hline & & Winter barley & 4.2 \\
\hline & & Winter barley & 2.0 \\
\hline & & Winter pea & 2.0 \\
\hline & & Winter pea & 8.3 \\
\hline & & Overall mean & $3.8(2.5)$ \\
\hline & & Perm. grass & \\
\hline & & Grass field & 33.0 \\
\hline & & Grass field & 27.0 \\
\hline & & Grass field & 29.2 \\
\hline & & Grass field & 31.3 \\
\hline & & Overall mean & $30.1(2.6)$ \\
\hline
\end{tabular}

Perm., permanent. Each grid of 25 snap traps was operated for three consecutive nights for 75 trap-nights per grid. Numbers in parentheses are standard deviations. 
peared that the vole population had already begun to crash. Most rodents captured were deer mice $(87.4 \%)$, whereas only $12.6 \%$ were voles. We noted some dead voles on the surface that appeared to be in good body condition. In this region, voles are a cyclic (3-5 year peaks) species; however, deer mice populations are not cyclic. Although it is not known exactly what drives the cycles in vole populations (Birney et al. 1976; Krebs 1996; Ylonen et al. 2003), vegetation, disease, and predation may play roles. In a study of voles in enclosures in Oregon, Wolff and Edge (2003) reported a sharp decline in abundance from spring to fall in 1999. They did not believe that the decline was caused by food shortages, predation, or self-regulation, but rather, was consistent with an epizootic by a disease such as tularemia.

By the spring 2002 trapping session, rodent densities were very low, as reflected by the much lower capture rates than were found in the previous fall (Table 1). The capture rates in the crop fields were similar in barley, wheat, and pea fields (5.0 captures per $100 \mathrm{t}-\mathrm{n}$ ), but this may be partly due to the low height of crops $(2.5-7.5 \mathrm{~cm})$ at this early growth stage. Researchers have noted the importance of grassy areas to voles and other rodents (Randall \& Johnson 1979). The collapse in the vole population continued, as only nine voles were captured in 250 trap-nights (3.6 per $100 \mathrm{t}$-n), despite efforts to find colonies in grass fields. Very few, if any, signs of rodents were observed in the rodent metal barrier exclosures, but this may be a reflection of low overall rodent numbers.

In the fall 2002 trapping session, the emphasis was on comparing capture rates between rodent management treatment areas and comparable control areas (see subsection below). All crop fields had been harvested so we could not compare capture rates in unharvested crop fields with the previous fall capture rates. We did note, however, that the capture rates in grass fields (30.2 per $100 \mathrm{t}-\mathrm{n}$ ) were very comparable with those of grass fields the previous fall (27.0 per $100 \mathrm{t}-\mathrm{n})$ and the capture rates in stubble fields of fall 2001 (6.7 per $100 \mathrm{t}-\mathrm{n})$ were very comparable to those of fall 2002 (3.8 per $100 \mathrm{t}-\mathrm{n} ; F=26.2$, d.f. $=3, P<0.0001)$.

\section{Rodent habitat use in relation to landscape variables}

We captured 2042 rodents in Sherman live traps and used logistic regression to conduct an exploratory analysis of variables measured at trap sites that were potentially associated with rodent capture and distribution over the farm landscape (Table 2). Because of the collapse of the vole population, $98.5 \%$ of these captures were deer mice. Capture rates per 100 trap-nights varied by season: $16.2 \%$ in the fall, $53.5 \%$ in the winter, $40.2 \%$ in the spring, and $18.1 \%$ in the summer. It is possible that the lower capture rates in the summer and fall were because of the smaller amounts of cover and food available in the fields. The areas of consistently high capture success were the permanent grassy areas. Several researchers have noted the importance of grassy borders as refugia for rodents and the need to control those populations to reduce the influx into crop fields once they are growing (Clark 1984; Edge et al. 1995; Martinelli \& Neal 1995; Chambers et al. 1996). Crop fields had much lower rates of capture, especially after crop harvest. An area of the PCFS that has permanent tree cover also had very low capture rates. Working with house mice in Australian croplands, Chambers et al. (1996) also noted much heterogeneity in habitat use by mice, with higher capture rates in ripe summer crops and harvested fields with substantial amounts of stubble. They also noted that few mice were captured in fallow fields with very short stubble or in plowed fields.

In all seasons except winter, permanent grass cover at the trap site was significantly and positively related to rodent captures (Table 2). However, in winter, grain stubble had a stronger relationship with rodent capture and was retained in the logistic model instead of grass cover. The statistical importance of other ecological variables varied by season (Table 2).

In fall, rodent captures were greater in grass cover and at higher elevations on the rolling topography of the farm (Table 2). In winter, capture rates were higher in grain stubble and increased with greater amounts of habitat edge occurring within $20 \mathrm{~m}$ of the trap site. In spring, capture rates were higher in grass and winter wheat cover, but the amount of edge habitat near the trap site was negatively associated with capture rates. In summer, capture rates were lower in barley stubble, and higher in grass cover, at higher elevations, and at greater distances from the field edge. Several variables (slope, aspect, PYSR index, soil moisture index, and distance to nearest edge) had no significant relationship with capture probability. The logistic regression models that included significant landscape variables predicted variations in the probability of rodent capture ranging from 5 to $95 \%$ in different farm habitats. Overall, however, the models explained relatively small amounts of the total variation in capture rates $\left(R^{2}=0.04-0.14\right.$; Table 2$)$. The logistic capture models primarily demonstrated the importance of grass and grain stubble cover types, and spatial factors of 
G. Witmer et al.

Table 2 Results of logistic regression of landscape variables associated with seasonal capture rates of rodents at the Palouse Conservation Field Station, Pullman, Washington, 2003-2004

\begin{tabular}{|c|c|c|c|c|}
\hline Season & Model $R^{2}$ & Variable & $P$-value & Odds ratio \\
\hline \multirow[t]{2}{*}{ Fall } & 0.10 & Grass & $<0.001$ & 3.64 \\
\hline & & Elevation & 0.004 & 0.14 \\
\hline \multirow[t]{2}{*}{ Winter } & 0.04 & Grain stubble & $<0.001$ & 0.25 \\
\hline & & Meters of edge & 0.021 & 0.24 \\
\hline \multirow[t]{3}{*}{ Spring } & 0.04 & Grass & $<0.001$ & 2.21 \\
\hline & & Winter wheat & $<0.001$ & 2.51 \\
\hline & & Meters of edge & 0.04 & 2.75 \\
\hline \multirow[t]{4}{*}{ Summer } & 0.14 & Grass & $<0.001$ & 0.31 \\
\hline & & Elevation & $<0.001$ & 0.07 \\
\hline & & Barley stubble & 0.020 & 2.42 \\
\hline & & Distance to edge (m) & 0.09 & 0.22 \\
\hline
\end{tabular}

Chi-square test values by season: fall, $\chi^{2}=49.0$, d.f. $=2$; winter, $\chi^{2}=24.8$, d.f. $=4$; spring: $\chi^{2}=26.8$, d.f. $=3$; summer, $\chi^{2}=94.7$, d.f. $=4$. For all models, $P<0.0001$.

elevation and field edge and interior habitats as basic ecological factors related to rodent distribution over the farm landscape.

\section{Rodent food habits}

Variation in food habits was found between the two major rodent species (voles versus deer mice), and there were also some notable seasonal differences in food habits (Table 3). As might be expected in this agricultural landscape, crops (wheat, barley, pea, and corn) were important to both species in the fall and spring, being found with a frequency of $50-91 \%$ of the rodents' stomach contents. Insects were also important to deer mice (occurring in $9-12 \%$ of stomach contents), but not voles $(<2 \%)$. Grasses occurred in $7.5-10 \%$ of vole stomach contents, but were rare in deer mice $(<2 \%)$. Root material was important to voles $(20.1 \%)$ in the fall, but not spring (1.2\%), whereas root material was unimportant to deer mice $(<1 \%)$. Forbs (such as pigweed and thistle) were important to both voles $(17.8 \%)$ and deer mice $(14.4 \%)$ in the fall, but only to deer mice in the spring $(11.7 \%$ versus $0.4 \%$ for voles). Deer mice are known to be habitat generalists, omnivorous, able to utilize a variety of crop fields, and able to readily exploit seed sources (Johnson 1987; Martinelli \& Neal 1995; Yunger 2002). Voles, on the other hand, are more specialized, well adapted to grassy habitats, and are more strictly herbivores, feeding on green vegetation when available, but also using seeds and roots (O'Brien 1994; Pugh et al. 2003). Most often, the foods found in specific stomachs were related to the field type that the rodent was captured in. This would be consistent with the rodents not traveling far to forage in this diverse agricultural setting.

\section{Rodent damage to crop fields}

Rodent damage was noted in several winter pea fields in spring 2002. The percentage plant cover along transects in undamaged areas was significantly higher $(67.1$ and $67.8 \%)$ than in the damaged areas $(4.2 \%$ and $19.1 \%$; $F=344.7$, d.f. $=3, P<0.001)$. The plant cover in one of the metal barrier exclosures with no signs of rodents in a winter pea field was comparable (68\%) to the undamaged areas listed above. On the other hand, the other two metal barrier exclosures in winter pea fields had some signs of 
Table 3 Frequency of occurrence (\%) of food items in rodent stomachs by date and species, Palouse Conservation Field Station, Pullman, Washington, 2001-2002

\begin{tabular}{lccccc}
\hline & \multicolumn{2}{c}{ Collection date } \\
\multirow{2}{*}{ Food item } & \multicolumn{2}{c}{ September 2001 } & \multicolumn{2}{c}{ April 2002 } & September 2002 \\
& Vole & Deer mouse & Vole & Deer mouse & Deer mouse \\
\hline Grain plants & 49.7 & 74.6 & 91.0 & 76.9 & 84.3 \\
Grasses (Poa, Festuca) & 10.4 & 0.6 & 7.5 & 1.7 & 0.7 \\
Dicots (thistle, pigweed) & 17.8 & 14.4 & 0.4 & 11.7 & 2.0 \\
Root material & 20.1 & 0.0 & 1.2 & 0.4 & 0.1 \\
Insects & 1.9 & 10.1 & 0.0 & 8.9 & 12.1 \\
\hline
\end{tabular}

${ }^{\dagger}$ No voles were captured in September, 2002. ${ }^{\ddagger}$ There were also occasional traces of moss, spores, pollen, and berries.

rodents and these had somewhat lower $(63.3 \%$ and $56.3 \%$ ) levels of plant cover.

Patches ("eat-out" areas) numbering between 12 and 25 were noted in three winter pea fields. Area measurements indicated that the plants had been removed from approximately $6.1 \%$ of the total area of those fields (range $=2.9-9.0 \%$ ). Each of those areas may have been occupied by a colony of voles during a portion of winter, with the damage occurring under snow cover. Voles are known to reproduce during the winter under snow cover, especially if green foods are available (Negus et al. 1977; Jannett 1984; Johnson 1987), whereas winter breeding by deer mice is very rare (Jannett 1984). We did not monitor vole reproduction in winter in our study, however, because of the difficulty of trapping rodents in a non-destructive way with heavy snow cover. Bergeron and Jodoin (1994) noted that voles can maintain an adequate diet in winter by selective foraging. Consequently, where substantial winter damage occurred, we surmise that voles were probably the rodent species involved. Conversely, much of the damage in no-till crops in the Midwestern states occurs to sprouting plants in the spring (Clark \& Young 1986; Johnson 1986). The damage level can be low or relatively high and is thought to be caused mainly by deer mice rather than voles (Clark \& Young 1986; Johnson 1986).

Based on estimates of vole food requirements and densities, Grodzinski et al. (1977) surmised that voles had little impact on winter wheat production during low population years and that only $2-3 \%$ of the crop was destroyed in periods of high density. We had higher levels of damage than $2-3 \%$ in our winter pea fields during a low vole density period and agree with Johnson (1987) who suggested that high levels of vole damage can occur in no-till fields under conditions of high population density.

\section{Trials to reduce rodent populations and damage}

The trapping session of fall 2002 focused on the differences in rodent relative abundance between the treated areas and untreated (control) areas. Although few signs of rodents were observed early in the spring in the nine metal rodent exclosures, by fall, more rodents were captured in them than in surrounding untreated portions of crop fields, although the differences were not significant $(t=2.96$, d.f. $=2, P=0.095)$. Captures in winter barley exclosures were 23.5 per $100 \mathrm{t}-\mathrm{n}$, while they were 11.1 per $100 \mathrm{t}-\mathrm{n}$ in both winter pea and winter wheat fields. Surrounding untreated areas had only 2.1-3.5 captures per $100 \mathrm{t}$-n. This difference in capture rates was probably a result of the crop fields around the exclosures having been already harvested, whereas the crop within the relatively small exclosures had not been harvested at the time of the trapping session. It would appear that while the metal barrier exclosures may have protected plants initially, they were eventually breached and occupied by rodents. Once crops were taller than the $25 \mathrm{~cm}$ of the barrier, the rodents could have climbed the plants to enter the exclosures. Furthermore, rodents may have accessed the interior of the exclosures by burrowing below the 25 $\mathrm{cm}$ of buried metal, although it is our experience that vole and deer mice burrows do not usually extend that deep. While we observed some burrow openings within the barriers, none of the burrows extended below the barrier 
itself. Timm and Howard (1994) noted that deer mice mainly use natural openings or the burrows of other animals for their nests and shelter. Pugh et al. (2003) noted that vole nests are usually only about $12 \mathrm{~cm}$ below the surface. The metal barrier walls also failed to result in lower rodent numbers in crop fields behind the barriers $(t$ $=2.7$, d.f. $=3, P=0.11$ ). In areas behind the three walls where rodents had been removed about a year earlier, there were 6.9 rodent captures per $100 \mathrm{t}$-n, whereas untreated areas in the same fields yielded 2.8 rodents per $100 \mathrm{t}-\mathrm{n}$.

The portions of fields that had been broadcast-baited with the zinc phosphide rodenticide on oats were also surveyed in fall 2002, about 10 months after the bait had been applied. By waiting this length of time, all crop cycles were complete before the rodent population was disturbed by snap trapping. Similar numbers resulted from baited (30.2 captures per $100 \mathrm{t}-\mathrm{n}$ ) and unbaited (30.2 per $100 \mathrm{t}-\mathrm{n})$ areas of permanent grass fields. As in previous trapping sessions, fewer rodents were captured in crop fields (in this case, winter peas; approximately 5.5 per $100 \mathrm{t}-\mathrm{n}$ ) than in the permanent grass fields. However, similar numbers were captured in the baited winter pea areas (5.2 per $100 \mathrm{t}-\mathrm{n})$ and the unbaited areas (6.3 per 100 $t-n)$. While broadcast-baiting can effectively and quickly reduce rodent numbers (Witmer \& Fantinato 2003), the effect does not last very long, especially in agricultural areas such as the PCFS. Johnson (1987) noted that zinc phosphide treatment resulted in only a brief population decline in voles in the Pacific Northwest. In studies in Midwestern states, Hygnstrom et al. (2000) noted that in-furrow drilling of zinc phosphide pellets reduced vole damage, but only by $7-34 \%$. Interestingly, we also had a grid of snap traps in a regular corn field in fall 2002, and a much higher rodent capture rate $(25$ per $100 \mathrm{t}-\mathrm{n})$ resulted than in the winter pea fields. We note that some of the highest rodent capture rates in the fall 2001 trapping session were in corn fields.

\section{Management implications and conclusions}

This study and others have demonstrated that voles, and occasionally other rodent species, can cause substantial damage to growing crops. It is difficult to predict damage, however, because of the multi-year cycles in vole population densities. For this reason, it is important to monitor vole populations. Witmer and VerCauteren (2001) review methods for monitoring vole populations.

Perhaps the most important approach for preventing rodent damage to growing crops is to lower the rodent carrying capacity of the grassy borders of the crop fields.
These areas provide refugia or harborage for rodents when crop fields are inadequate to support many rodents and also sustain voles during lows in their population cycles. Management actions can include mowing, burning, herbicide application, and the use of rodenticides (Witmer \& VerCauteren 2001; Brown et al. 2004). Rodenticides should be used judiciously in order to be effective, to minimize non-target hazards, and to be cost-effective. Ramsey and Wilson (2000) discuss ecologically-based baiting strategies for rodents in agricultural systems.

Research should continue to seek ways to reduce rodent populations and damage to agriculture. Some promising areas of research include the use of endophytic (alkaloid-producing) grasses in non-production areas (Fortier et al. 2000) and fertility control (Miller et al. 1998).

\section{ACKNOWLEDGMENTS}

We would like to thank PCFS farm manager Mr Derek Appel for his assistance with logistics in this study. $\mathrm{Mr}$ Dave Uberuaga, Washington State University, assisted with GPS equipment, GIS software, and field mapping. Mr Patrick Burke, Biological Science Technician at NWRC, assisted with data analyses and manuscript preparation. This study was supported, in part, by a grant from the US Department of Agriculture Cooperative State Research, Education, and Extension Service, Cool Season Food Legume Research Program.

\section{REFERENCES}

Bergeron J, Jodoin L (1994). Comparison of food habits and of nutrients in the stomach contents of summerand winter-trapped voles. Canadian Journal of Zoology $72,183-7$.

Birney E, Grant W, Baird D (1976). Importance of vegetative cover to cycles of Microtus populations. Ecology 57, 1043-51.

Bourne J (1999). Controlling Wildlife Damage in Direct Seeding Systems. Agdex 519-16. Alberta Agriculture, Food and Rural Development, Edmonton, Alberta.

Brown P, Davies M, Singleton G, Croft J (2004). Can farm management practices reduce the impact of house mouse populations on crops in an irrigated farming system? Wildlife Research 31, 597-604.

Campbell G, Norman J (1998). Chapter 11. In: An Introduction to Environmental Biophysics. Springer-Verlag, New York, NY.

Capelli J (2005). Landscape ecology of rodents in a no-till agriculture system (MS thesis). Washington 
State University, Pullman, WA.

Chambers L, Singleton G, van Wensveen M (1996). Spatial heterogeneity in wild populations of house mice on the Darling Downs, Southeastern Queensland. Wildlife Research 23, 23-38.

Clark J (1984). Vole control in field crops. Proceedings of the Vertebrate Pest Conference 11, 5-6.

Clark J (1994). Vertebrate Pest Control Handbook, 4th edn. California Department of Food and Agriculture, Sacramento, CA.

Clark W, Young R (1986). Crop damage by small mammals in no-till cornfields. Journal of Soil and Water Conservation 41, 338-41.

Conover M (1998). Perceptions of American agricultural producers about wildlife on their farms and ranches. Wildlife Society Bulletin 26, 597-604.

Edge W, Wolff J, Carey R (1995). Density-dependent responses of gray-tailed voles to mowing. Journal of Wildlife Management 59, 245-51.

Fortier G, Bard N, Jansen M, Clay K (2000). Effects of tall fescue endophyte infection and population density on growth and reproduction in prairie voles. Journal of Wildlife Management 64, 122-8.

Grodzinski W, Makomaska M, Tertil R, Weiner J (1977). Bioenergetics and total impact of vole populations. Oikos 29, 494-510.

Guy S, Cox D (2002). Reduced tillage increases residue groundcover in subsequent dry pea and winter wheat crops in the Palouse region of Idaho. Soil and Tillage Research 66, 69-77.

Hammond R, Stinner B (1999). Impact of tillage systems on pest management. In: Ruberson J, ed. Handbook of Pest Management. Marcel Dekker, New York, NY, pp. 693-712.

Hines R, Hygnstrom S (2000). Rodent damage control. In: Reader R, ed. Conservation Tillage Systems and Management. Midwest Plan Service, Iowa State University, Ames, IA, pp. 167-76.

Holtzer T, Anderson R, McMullan M, Peairs F (1996). Integrated pest management of insect pests, weeds, and plant diseases in dryland agricultural systems. Journal of Production Agriculture 9, 200-8.

Hygnstrom S, VerCauteren K, Hines R, Mansfield C (2000). Efficacy of in-furrow zinc phosphide pellets for controlling rodent damage in no-till corn. International Biodeterioration and Biodegradation 45, $215-22$

Jannett F (1984). Reproduction of the montane vole in subnivean populations. Special Publication of Carnegie Museum of Natural History 10, 215-24.
Johnson D (1987). Effect of alternative tillage systems on rodent density in the Palouse region. Northwest Science 61, 37-40.

Johnson R (1986). Wildlife damage in conservation tillage agriculture: a new challenge. Proceedings of the Vertebrate Pest Conference 12, 127-32.

Johnson R, Koehler A, Burnside O, Lowry S (1985). Response of thirteen-lined ground squirrels to repellents and implications for conservation tillage. Wildlife Society Bulletin 13, 317-24.

Kogan M, Lattin J (1999). Agricultural systems as ecosystems. In: Ruberson J, ed. Handbook of pest management. Marcel Dekker, New York, NY, pp. 1-33.

Krebs C (1996). Population cycles revisited. Journal of Mammalogy 77, 8-24.

Martinelli L, Neal D (1995). The distribution of small mammals on cultivated fields and in rights-of-way. Canadian Field-Naturalist 109, 403-7.

Merkens M, Harestad A, Sullivan T (1991). Cover and efficacy of predator-based repellents for Townsend's vole. Journal of Chemical Ecology 17, 401-12.

Miller L, Johns B, Elias D (1998). Immunocontraception as a wildlife management tool: some perspectives. Wildlife Society Bulletin 26, 237-43.

Mueller-Dombois D, Ellenberg H (1974). Aims and Methods of Vegetation Ecology. John Wiley, New York, NY.

Negus N, Berger P, Forslund L (1977). Reproductive strategy of Microtus montanus. Journal of Mammalogy 58, 347-53.

Nowak R (1991). Walker's Mammals of the World, 5th edn, Vol. II. The Johns Hopkins Press, Baltimore, MD.

O’Brien J (1994). Voles. In: Hygnstrom S, Timm R, Larsen G, eds. Prevention and Control of Wildlife Damage. Cooperative Extension Division, University of Nebraska, Lincoln, NE, pp. B-177-82.

Owsiak A (1996). A comparison of intensive sheep grazing and free-range cattle grazing for the reduction of pocket gopher populations on reforested rangelands (MS thesis). Washington State University, Pullman, WA.

Phillips R, Blevins R, Thomas G, Frye W, Phillips S (1980). No-tillage agriculture. Science 208, 1108-13.

Pugh S, Johnson S, Tamarin R (2003). Voles. In: Feldhamer G, Thompson B, Chapman J, eds. Wild Mammals of North America. The Johns Hopkins University Press, Baltimore, MD, pp. 349-70.

Ramsey D, Wilson J (2000). Towards ecologically-based baiting strategies for rodents in agricultural systems. International Biodeterioration and Biodegradation 45, 
183-97.

Randall J, Johnson R (1979). Population densities and habitat occupancy by Microtus longicaudus and $M$. montanus. Journal of Mammalogy 60, 217-9.

Roberts D, Cooper S (1989). Land Classifications Based on Vegetation: Applications for Resource Management. US Department of Agriculture Forest Service General Technical Report INT-257, Ogden, UT.

Timm R, Howard W (1994). White-footed and deer mice. In: Hygnstrom S, Timm R, Larsen G, eds. Prevention and Control of Wildlife Damage. Cooperative Extension Division, University of Nebraska, Lincoln, NE, pp. B-47-51.

Wilson JP, Gallant JC (2000). Chapter 4: Secondary topographic attributes. In: Wilson JP, Gallant JC, eds. Terrain Analysis: Principles and Applications. John Wiley, New York, NY.

Witmer G, Fantinato J (2003). Management of rodents at airports. Proceedings of the Wildlife Damage Management Conference 10, 350-8.

Witmer G, VerCauteren K (2001). Understanding vole problems in direct seeding-strategies for management. In: Veseth R, ed. Proceedings of the Northwest Direct Seed Cropping Systems Conference. Northwest Direct Seed Conference, Pasco Washington, pp. 104-10.

Witmer G, Fall M, Fiedler L (1995). Rodent control, research needs, and technology transfer. In: Bissonette
J, Krausman P, eds. Integrating People and Wildlife for a Sustainable Future: Proceedings of the First International Wildlife Management Congress. The Wildlife Society, Bethesda, MD, pp. 693-7.

Witmer G, Hakim A, Moser B (2000). Investigations of methods to reduce damage by voles. Proceedings of the Eastern Wildlife Damage Control Conference 9, $357-65$.

Wolff J, Edge D (2003). A retrospective analysis of a vole population decline in western Oregon, USA. In: Singleton G, Hinds L, Krebs C, Spratt D, eds. Rats, Mice, and People: Rodent Biology and Management. ACIAR Monograph No. 96. Australian Centre for International Agricultural Research, Canberra, pp. $47-50$.

Wywialowski A (1994). Agricultural producer's perceptions of wildlife-caused losses. Wildlife Society Bulletin 22, 370-82.

Ylonen H, Eccard J, Sundell J (2003). Boreal vole cycles and vole life histories. In: Singleton G, Hinds L, Krebs C, Spratt D, eds. Rats, Mice, and People: Rodent Biology and Management. ACIAR Monograph No. 96. Australian Centre for International Agricultural Research, Canberra, pp. 137-42.

Yunger J (2002). Response of two low-density populations of Peromyscus leucopus to increased food availability. Journal of Mammalogy 83, 267-79. 